\title{
THE KATHMANDU DECLARATION OF THE SAARC
}

\author{
South Asian Association for Regional Cooperation
}

\author{
HEADS OF STATE OR GOVERNMENT:
}

\author{
ELEVENTH MEETING
}

Kathmandu, 4 - 6 January 2002

\section{SAARC/SUMMIT.11/12 \\ DECLARATION OF THE ELEVENTH SAARC SUMMIT}

The Prime Minister of the People's Republic of Bangladesh, Her Excellency Begum Khaleda Zia; the Prime Minister of the Royal Government of Bhutan, His Excellency Lyonpo Khandu Wangchuk; the Prime Minister of the Republic of India, His Excellency Mr. Atal Behari Vajpayee; the President of the Republic of Maldives, His Excellency Mr. Maumoon Abdul Gayoom; the Prime Minister of the Kingdom of Nepal, Right Honourable Mr. Sher Bahadur Deuba; the President of the Islamic Republic of Pakistan, His

Excellency General Pervez Musharraf; and the President of the Democratic Socialist Republic of Sri Lanka, Her Excellency Mrs. Chandrika Bandaranaike Kumaratunga met at the Eleventh Summit meeting of the South Asian Association for Regional Cooperation (SAARC) in Kathmandu, Nepal from 4 to 6 January 2002.

\section{Regional Cooperation}

1. The Heads of State or Government reaffirmed their commitment to regional cooperation through SAARC and underscored the importance of annual Summit meetings in charting common strategies for the realization of the objectives and principles set out in the Charter of the Association. Meeting for the first time at the dawn of the new millennium, they solemnly renewed their pledge to strengthen the Association and make it more cohesive, result oriented, and forward looking, by adopting clearly defined programmes and effective implementation strategies in line with popular expectations. To give effect to the shared aspirations for a more prosperous South Asia, the Leaders agreed to the vision of a phased and planned process eventually leading to a South Asian Economic Union.

Asian Yearbook of International Law, Volume 11 (B.S. Chimni et al., eds.)

(C) 2006 Koninklijke Brill NV. Printed in The Netherlands, pp. 361-372. 
2. The Heads of State or Government stressed that equitable sharing of the benefits of regional cooperation is essential to achieve and maintain a minimum acceptable level of economic and social development in each Member State. To this end, they expressed their commitment to a speedier process of harmonizing the policies and practices, and imbibing regional goals and strategies in their national development programmes.

3. The Heads of State or Government expressed their firm determination fully to benefit from the wealth of traditional wisdom, creativity, and enterprise in the region. They also pledged to enhance transparency and accountability in governance, and to encourage effective participation of the peoples and civil societies in the formulation as well as the implementation of the programmes of cooperation.

4. Reiterating their resolve to promote the regional identity and to strengthen cooperation at the international level, the Heads of State or Government also emphasized the need to evolve common positions on issues of shared interests at the international fora.

\section{Cooperation in the Economic Sector}

5. The Heads of State or Government agreed to accelerate cooperation in the core areas of trade, finance, and investment to realize in a step-by-step manner the goal of an integrated South Asian economy. They expressed their determination to make full use of regional synergy to maximize the benefits of globalization and liberalization, and to minimize their negative impacts on the region. While recognizing that trade and economic expansion are closely inter-linked, the Leaders made a commitment to widen and deepen the scope of regional networks of activities in trade and financial matters.

6. The Heads of State or Government noted with satisfaction the outcomes of the successive meetings of the SAARC Commerce Ministers aimed at enlarging the scope of cooperation in the core areas. They recognized the importance of achieving a free trade area and reaffirmed that the treaty regime for creating a free trade area must incorporate, inter alia, binding time-frames for freeing trade, measures to facilitate trade, and provisions to ensure an equitable distribution of the benefits of trade to all states, especially for small and least developed countries, including mechanisms for compensation of revenue loss.

7. Recognizing the need to move quickly towards a South Asian Free Trade Area, the Heads of State or Government directed the Council of Ministers to finalize the text of the Draft Treaty Framework by the end of 2002. They also directed that in moving towards the goal of SAFTA, the Member States expedite action to remove tariff and non-tariff barriers, and structural impediments to free trade. They were also instructed to conclude the meeting of the Inter-Governmental Group on Trade 
Liberalization for the Fourth Round of Trade Negotiations under SAPTA as early as possible as per the decision of the Tenth SAARC Summit in Colombo.

8. The Heads of State or Government renewed their commitment to encourage the participation of the private sector and assured their full support for their socially responsible economic initiatives. While welcoming the practice of holding trade fairs in cooperation with the private sector at the regional level, they appreciated the efforts of the SAARC Chamber of Commerce and Industry to promote regional economic cooperation in the spirit of public and private sector partnership.

9. The Heads of State or Government also decided to instruct the SecretaryGeneral to facilitate an early finalization of a regionally agreed investment framework to meet the investment needs of the SAARC Member States.

10. The Heads of State or Government recognized the immense tourism potential of South Asia and underlined the need to take measures to promote South Asia as a common tourist destination through joint efforts in areas such as the upgrading of infrastructure, air linkages, the simplification and harmonization of administrative procedures, and training and joint marketing.

\section{Poverty Alleviation}

11. The Heads of State or Government acknowledged that investment in poverty alleviation programmes contributes to social stability, economic progress, and overall prosperity. They were of the view that widespread and debilitating poverty continued to be the most formidable developmental challenge for the region. Conscious of the magnitude of poverty in the region, and recalling also the decision of the UN Millennium Summit 2000 to reduce world poverty by half by 2015, and also recalling the commitments made at the Eve year review of the World Summit for Social Development to reduce poverty with enhanced social mobilization, the Heads of State or Government made a review of the SAARC activities aimed at poverty alleviation and decided to reinvigorate them in the context of the regional and global commitments to poverty reduction.

12. The Heads of State or Government expressed their firm resolve to combat the problem of poverty with a new sense of urgency by actively promoting the synergetic partnership among national governments, international agencies, the private sector, and the civil society. They reaffirmed their pledge to undertake effective and sustained poverty alleviation programmes through pro-poor growth strategy and social as well as other policy interventions with specific sectoral targets. The Leaders also agreed to take immediate steps for an effective implementation of the programmes for social mobilization and decentralization, and for strengthening institution building, and of support mechanisms to ensure participation of the poor, both as stake-holder and beneficiary, in governance and the development process. 
13. The Heads of State or Government decided to undertake sustained measures to extend rural micro-credit programmes with a focus on women and the disadvantaged sections of the society. They also stressed the need for widening the opportunities for gainful employment. While highlighting the importance of promoting agriculture, indigenous skills, and small scale and cottage industries to address the incidence of rural poverty, they decided to enhance cooperation in agricultural research extension and adoption. They specifically instructed that the Technical Committees should identify programmes and activities that impact on poverty alleviation. They urged the need to create gainful employment and promote cooperation in vocational training.

14. The Heads of State or Government emphasized the need to promote the sharing of best practices and experiences among the Member States and, to this end, instructed the Secretary-General to disseminate such information to the Member States on a regular basis. They directed the Council of Ministers to review on a continuous basis the regional poverty profile to be prepared by the Secretary-General with the assistance of the related UN agencies, nodal agencies, and independent research institutions specialized in the field.

15. In order to ensure social stability and to protect the vulnerable sections of the population from the adverse impacts of globalization and liberalization, the Heads of State or Government stressed the need to enhance cooperation to create and maintain appropriate safety nets.

16. The Heads of State or Government agreed that a special session on poverty alleviation at the Ministerial level should undertake a comprehensive review and evaluation of the status of implementation of poverty eradication policies and programmes carried out so far, and to recommend further concrete measures to enhance effective cooperation at the regional level to the Twelfth SAARC Summit. They also directed the Council of Ministers to take necessary steps fully to activate the existing three-tier mechanism for poverty alleviation.

17. The Leaders directed the Council of Ministers to coordinate efforts to integrate poverty alleviation programs into the development strategies of Member States. In this context, they agreed to reconstitute the Independent South Asian Commission on Poverty Alleviation, with Nepal as its Convenor and Bangladesh as Co-convenor, for reviewing the progress made in cooperation on poverty alleviation, and for suggesting appropriate and effective measures. They instructed the Chairman of the Council of Ministers to seek two nominations from each Member State by end of January 2002 to enable its first meeting to be held before the proposed Ministerial Meeting on Poverty Alleviation in Pakistan in April 2002.

18. Expressing concern at the region's special vulnerability in the slow-down in world economy and its negative impact on the poor and the marginalized, the Heads of State or Government called for a supportive international environment and 
enhanced level of assistance by international community for poverty alleviation programmes in South Asia.

\section{Cooperation in the Social and Cultural Sector}

19. The Heads of State or Government reiterated the need for an early finalization of the SAARC Social Charter and instructed the Inter-Governmental Expert Group to expedite their work on the basis of the draft submitted by the Secretary-General as a working paper for its consideration, to complete the draft framework of the Charter as early as possible, and to present it for consideration at the next meeting of the Council of Ministers. While drawing up the Charter, they also directed the Council of Ministers to include the important areas of poverty eradication, population stabilization, empowerment of women, youth mobilization, human resources development, the promotion of health and nutrition, and the protection of children.

20. The Leaders recognized the debilitating and widespread impact of the HIV/ AIDS, TB and other communicable deadly diseases on the population of South Asia, and stressed the need for evolving a regional strategy to combat these diseases. The strategy should include, inter alia, culturally appropriate preventive measures and an affordable treatment regime, and should especially target the vulnerable groups. In this regard, they felt that SAARC should collaborate with the international organizations and civil society on those diseases. They also emphasized that the SAARC Tuberculosis Centre in Kathmandu should play a coordinating role in the related areas.

21, In accordance with the Colombo Declaration, the Heads of State or Government decided to mandate the Ministers of Cultural Affairs Meeting in Sri Lanka to finalize the details relating to the establishment as well as the financing of the SAARC Cultural Centre, and submit its report to the next session of the Council of Ministers.

\section{Women and Children}

22. The Heads of State or Government welcomed the signing of the SAARC Convention on Preventing and Combating the Trafficking in Women and Children for Prostitution, and expressed their collective resolve to treat trafficking in women and children for the commercial sexual exploitation as a criminal offence of a serious nature. They also welcomed the signing of the SAARC Convention on Regional Arrangements for the Promotion of Child Welfare in South Asia and observed that the Convention reflected their commitment to place the child first in the national and regional programmes of the Member States. They instructed the SecretaryGeneral, in consultation with Member States and other specialized agencies, to present a report on measures for the effective implementation of the Conventions to the next meeting of the Council of Ministers.

23. The Heads of State or Government agreed to establish, on the basis of recommendations of the Regional Task Force responsible for the implementation 
of the provisions of the SAARC Convention on Preventing and Combating Trafficking in Women and Children for Prostitution, a voluntary fund with contributions from Member States, individuals, and donor countries and agencies for the rehabilitation and re-integration of the victims of trafficking.

24. The Leaders recognized the need to form an autonomous advocacy group of prominent women personalities from the Member States with a view to making recommendations to the SAARC bodies on a broad spectrum of gender-related issues. They directed the Council of Ministers to take necessary steps to prepare and present for consideration at their next meeting the Terms of Reference for the purpose.

25. The Heads of State or Government recognized the need actively to pursue and promote social development through the empowerment of women, and to achieve their full participation in decision making at all levels. They reaffirmed their commitment to uplift the social status of the people, women and children in particular, in the region and expressed their common resolve to accord the highest priority to promoting social development through specific and targeted programmes. The Leaders directed the Council of Ministers to take necessary measures to ensure the enjoyment by women and girl children of their inherent potentials. They also directed the Council of Ministers to constitute a Task Force to review the status of implementation of past decisions related to the social sector and to suggest guidelines for their effective implementation in the future.

26. The Leaders directed the Council of Ministers to take concrete steps to give priority to investing in children as an effective means for poverty reduction in the long run. Reaffirming their commitment to the Colombo Plan of Action and the Rawalpindi Declaration and recalling the declaration of 2001 to 2010 as the SAARC Decade of the Rights of the Child, the Heads of State or Government noted with appreciation the South Asia High-level Meeting on Children held in Kathmandu in May 2001. They reaffirmed their conviction that the children in South Asia deserve urgent and focused attention to enhance the long-term and overall progress of the countries of the region.

27. The Heads of State or Government agreed to mobilize the necessary resources and intensify broad based actions to achieve a set of priority goals related to improving the status of children, such as polio eradication by 2005 , protection of children from mother-to-child transmission of HIV/AIDS, and quality basic education to the children, within a time-bound period.

\section{Education}

28. The Heads of State or Government instructed the concerned Ministries of the Governments to devise appropriate strategies for raising the quality of education through the exchange of information among the universities in the region. While emphasizing the importance of mutual recognition of the educational institutions, 
they agreed to give the necessary impetus to realize the goal of a common regional educational standard through uniform methods of instruction and teaching aids. They were unanimous in recognizing the benefit of introducing SAARC in the national curricula at appropriate levels of study in order to enhance awareness of the Association's goals and objectives.

29. The Heads of State or Government recognized that access to quality education was an important element for the empowerment of all segments of society, and undertook to develop or strengthen national strategies and action plans to ensure that all children, particularly girl children, have access to quality primary education by 2015; and to improve levels of adult literacy by fifty per cent by eliminating gender disparities in access to education as envisaged in the Dakar Framework for Action on Education for All adopted by the World Education Forum held at Dakar in April 2000 .

\section{International Political and Economic Environment}

30. The Heads of State or Government reiterated their firm support for the principles and purposes of the United Nations in order to create a just, balanced and equitable world order. They reaffirmed their commitment to continue working with the NAM and other like-minded countries for the reform and democratization of the United Nations System with a view to making it an effective and more democratic institution for international peace, security, progress, and cooperation.

31. The Heads of State or Government were of the view that stability, peace, and security in South Asia should be promoted together with efforts to improve the global security environment. They underscored their commitment to general and complete disarmament including nuclear disarmament on a universal basis, under effective international control. They agreed that global non-proliferation goals could not be achieved in the absence of progress towards nuclear disarmament and in this context called upon all nuclear weapon states, whether party or non-party to the NPT, to engage constructively through a transparent and credible process of negotiations at the Conference on Disarmament. The Leaders also recognized the linkage between disarmament and development.

32. The Leaders emphasized the need to take appropriate measures to make international financial institutions and the global trading regime more responsive to the needs and concerns of the developing countries. They reiterated the call for genuine partnership among the developed and developing countries in international trade and finance, and for the reform of the global financial architecture with the enhanced level of resources.

33. The Leaders also called upon the developed countries to facilitate and ensure an unimpeded and enhanced level of market access to products from the developing, the least developed, and the land-locked countries. 
34. Recognizing the important role that trade can play in advancing the overall development of a country, thus contributing to an equitable and sustainable world order, the Heads of State or Government also called for an early realization of a rulebased and non-discriminatory world trade regime. In this context, they appreciated the positive elements of the Fourth VVTO Ministerial Conference held in Doha and called upon the developed countries to fulfil their commitments to address the particular concerns and needs of the developing and the least developed countries. The Leaders also instructed the forthcoming meeting of the Committee on Economic Cooperation to devote at least half a day for discussions on the evaluation of the decisions of the recently concluded Doha conference in order to evolve better coordinated positions among the Member States on all WTO issues. They further stressed the need to intensify coordination among the SAARC missions in Geneva and to begin the necessary preparation to advance the common interest of the region in the Fifth WTO Ministerial conference.

35. The Heads of State or Government noted with serious concern the adverse impact of the shrinking Official Development Assistance (ODA) and other concessional financial flows on developing countries in general, and the least developed among them in particular. They further noted with concern the current trend of global economic slowdown and its adverse effects on these economies. Taking into account the interdependent nature of the global economy, the Leaders urged the developed countries to enhance the level of ODA flows to meet the internationally agreed targets.

36. Recalling the recommendations of the Third United Nations Conference on the Least Developed Countries held at Brussels in May 2001 and the decisions of the Zanzibar Declaration of July 2001, the Leaders urged the developed countries to adopt more liberal trade and aid policies responsive to the particular needs of the least developed countries. Referring to the forthcoming International Conference on Financing for Development to be held in Mexico in March 2002, the Leaders urged the international community to strengthen cooperation for development by addressing international and systemic issues related to financing for development in the developing and the least developed countries in a holistic manner.

37. The Heads of State or Government welcomed the initiative of the donor countries to relieve the external debt burden of the Highly Indebted Poor Countries. They urged the international donor community and financial institutions to widen the scope and extent of debt relief initiatives to cover all those developing and the least developed countries, which are facing developmental difficulties due particularly to the current global recession. In the context of growing global interdependence, they underlined the importance of forging cooperative partnership between the developed and the developing countries to ensure equitable benefits to all.

38. The Heads of State or Government expressed concern over the continued violence and bloodshed in the Middle East, and the set-backs suffered by the peace process. They reaffirmed their support for the achievement of a just, lasting and 
comprehensive peace based on Security Council Resolution 242 (1967) and Resolution 338 (1973), and the establishment of a sovereign Palestine State under the leadership of the PLO, which could co-exist with its neighbours in peace, security, and harmony.

\section{Security of Small States}

39. The Heads of State or Government recognized that due to their particular vulnerability, small states require special measures of support from the international community for the safeguarding of their sovereign independence and territorial integrity. They reiterated that the real protection of small states should be firmly rooted in scrupulous adherence to the UN Charter and the rule of law, and strict adherence to universally accepted principles and norms related to the sovereign rights and territorial integrity of all states, irrespective of size. This, they stressed, should be ensured by all countries, either severally or collectively through the pursuit of appropriate action.

\section{Terrorism}

40. The Heads of State or Government were convinced that terrorism, in all its forms and manifestations, is a challenge to all states and to all of humanity, and cannot be justified on ideological, political, religious or on any other ground. The Leaders agreed that terrorism violates the fundamental values of the United Nations and the SAARC Charter, and constitutes one of the most serious threats to international peace and security in the twenty-first century.

41. The Heads of State or Government emphasized the need for the urgent conclusion of a Comprehensive Convention on Combating International Terrorism. They also emphasized that international cooperation to combat terrorism should be conducted in conformity with the UN Charter, international law, and relevant international conventions.

42. The Heads of State or Government reiterated their support to United Nations Security Council Resolution 1373 of 28 September 2001 and affirmed their determination to redouble efforts, collectively as well as individually, to prevent and suppress terrorism in all its forms and manifestations, including by increased cooperation and full implementation of the relevant international Conventions relating to terrorism to which they are parties. In this context, they called on all states to prevent and suppress the financing of terrorist acts by criminalizing the collection of funds for such acts and refraining from organizing, instigating, assisting or participating in terrorist acts in states, or from acquiescing in organized activities within its territory directed towards the commission of such acts. The Leaders reaffirmed that the fight against terrorism in all its forms and manifestations has to be comprehensive and sustained. 
43. The Heads of State or Government were unanimous in recognizing the distinct and ominous link between terrorism, drug-trafficking, money laundering and other transnational crimes, and emphasized the need to coordinate efforts at the national and regional levels to strengthen the global response to this serious challenge and threat to international security. They called upon the international community to assist Member States of SAARC to deal effectively with the adverse economic effects of terrorism in general, and to meet the rising insurance and security related costs in particular.

44. The Heads of State or Government reaffirmed their commitment to SAARC Regional Convention on Suppression of Terrorism, which, among others, recognizes the seriousness of the problem of terrorism as it affects the security, stability, and development of the region. They also reiterated their firm resolve to accelerate the enactment of enabling legislation within a definite time-frame for the full implementation of the Convention, together with the strengthening of SAARC Terrorist Offences Monitoring Desk and the SAARC Drug Offences Monitoring Desk in an effective manner.

\section{Report of the Group of Eminent Persons}

45. The Leaders noted with appreciation that the Report of the Group of Eminent Persons (GEP) was an important contribution in the on-going process of introspection into the functioning of the Association as well as in setting out a perspective plan of action for it. They endorsed the report of the Council of Ministers on the implementation of the recommendations of the GEP Report, and directed the Council of Ministers to undertake a review of progress in this regard.

\section{Enhancing Political Cooperation}

46. The Heads of State or Government reaffirmed their commitment to the promotion of mutual trust and understanding and, recognizing that the aims of promoting peace, stability and amity, and accelerated socio-economic cooperation may best be achieved by fostering good-neighbourly relations, relieving tensions and building confidence, agreed that a process of informal consultations would prove useful in this regard. The Leaders further recognized that this process would contribute to the appreciation of each other's problems and perceptions as well as for decisive action in agreed areas of regional cooperation. They underlined the importance of consultations in promoting mutual understanding and reinforcing the confidence building process among the Member States.

\section{Sub-regional Cooperation}

47. The Heads of State or Government reaffirmed the validity of the idea of encouraging the development of specific projects relevant to the individual needs 
of three or more Member States under the provisions of Articles VII and X of the SAARC Charter

\section{South Asian Development Fund (SADF)}

48. The Heads of State or Government underlined the urgent need to make the South Asian Development Fund operational by making possible utilization of the existing funds. They also instructed the Secretary-General to submit a proposal for seeking assistance from possible regional and international sources for the implementation of specific regional poverty alleviation priority projects.

\section{Environment}

49. The Heads of State or Government noted with satisfaction the growing public awareness of the need for protecting the environment within the framework of regional cooperation. They reiterated their call for the early and effective implementation of the SAARC Environment Plan of Action as endorsed by the SAARC Environment Ministers. They directed their Environment Ministers to take this into account and come up with an agreed position in their forthcoming meeting.

50. The Heads of State or Government also felt a strong need to devise a mechanism for cooperation in the field of the early warning as well as preparedness and management of natural disasters along with programmes to promote conservation of land and water resources.

51. The Heads of State or Government also stressed the need to develop a cooperative mechanism for the protection, enrichment, and utilization of bio-diversity as provided for in the UN Convention on Biological Diversity and to establish a regional bio diversity database with a view to providing equitable benefits to all Member States. They also underscored the importance of protecting associated knowledge and other indigenous intellectual manifestations for the advancement of the region. They also directed the Council of Ministers to explore the possibility of establishing a SAARC Seed Security Reserve to strengthen cooperation in the field of agriculture and to protect IPRs of the seeds of the Reserve.

\section{People-to-People Contact}

52. The Heads of State or Government were unanimous in recognizing the need for further promoting a sense of regional identity amongst the peoples of the region. The Leaders lauded the roles played by the intellectuals, professionals and eminent persons in promoting people-to-people contacts within the region and agreed to encourage such endeavours as a healthy sign of regional cohesion and fraternity. In this context, they took note of the activities of the SAARCLAW, including other recognized bodies. They also took note of the First Meeting of the Chief Election Commissioners of SAARC Countries held in Kathmandu in February 1999 and 
appreciated the initiative on free and fair election. The Leaders instructed the Secretary-General to collect on a regular basis study reports and other relevant documents and information from the civil society on matters relating to regional cooperation for dissemination to Member States.

\section{Rationalization and Institutional Issues}

53. The Heads of State or Government were in agreement that the Summit and all other meetings of SAARC needed to be made more business-like and resultoriented with their focus on programmes and activities supported by informed regional inputs from cross-sections of society. They directed the Chairman of the Council of Ministers to undertake a review of the functioning and operation of the SAARC Secretariat, and to make recommendations, to advance the process of rationalization and to make SAARC more functional and business-like, to the next meeting of the Council of Ministers.

\section{SAARC Award}

54. The Heads of State or Government noted with appreciation the proposal made by Nepal to institute a SAARC Award to honour the outstanding work of individuals and organizations with the region in the fields of peace, development, poverty alleviation, and regional cooperation, and requested His Majesty's Government of Nepal to submit a concept paper for consideration by the next session of the Council of Ministers.

\section{Date and Venue of the Twelfth Summit}

55. The Heads of State or Government welcomed with appreciation the offer of the Government of the Islamic Republic of Pakistan to host the Twelfth Summit Meeting of the Heads of State or Government of the South Asian Association for the Regional Cooperation (SAARC) in Pakistan in early 2003.

56. The Heads of State or Government of Bangladesh, Bhutan, India, Maldives, Pakistan, and Sri Lanka expressed their deep appreciation for the exemplary manner in which the right Honourable Prime Minister of Nepal conducted the proceedings of the Eleventh SAARC Summit in his capacity as Chairperson. They also expressed their deep gratitude for the generous hospitality extended to them by His Majesty's Government and people of Nepal, and for the excellent arrangements made for the Summit. 